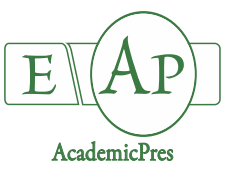

Huang X et al. (2021)

Notulae Botanicae Horti Agrobotanici Cluj-Napoca

Volume 49, Issue 2, Article number 12258

DOI: $10.15835 / \mathrm{nbha} 49212258$

Review Article

\title{
Root hair specification and its growth in response to nutrients
}

\author{
Xian HUANG ${ }^{1,3}$, Tianzhi GONG ${ }^{1,3}$, Mei LI ${ }^{1,3}$, Cenghong $\mathrm{HU}^{1,3}$, \\ Dejian $\mathrm{ZHANG}^{1,2,3 *}$, Mufang $\mathrm{SUN}^{2,3 * *}$
${ }^{1}$ Yangtze University, Hubei Key Laboratory of Waterlogging Disaster and Agricultural Use of Wetland, Jingzhou, Hubei 434020, P.R.China;3052369@qq.com;283583209@qq.com; meili_sky2021@163.com;1638287941@qq.com; zhangdejian0553@126.com (*corresponding author)
${ }^{2}$ Xinyang Agriculture and Forestry University, Henan Key Laboratory of Tea Plant Comprehensive Utilization in South Henan Xinyang, Henan 464000, China; xynzsmf@163.com ( ${ }^{* *}$ corresponding author)
${ }^{3}$ Yangtze University, College of Horticulture and Gardening, Jingzhou, Hubei 434025, China

\begin{abstract}
Plant root hairs are cylindrical tubular projections from root epidermal cells. They increase the root surface area, which is important for the acquisition of water and nutrients, microbe interactions, and plant anchorage. The root hair specification, the effect of root hairs on nutrient acquisition and the mechanisms of nutrients (calcium, iron, magnesium, nitrogen, phosphorus, and potassium) that affect root hair development and growth were reviewed. The gene regulatory network on root hair specification in the plant kingdom was highlighted. More work is needed to clone the genes of additional root hair mutants and elucidate their roles, as well as undertaking reverse genetics and mutant complementation studies to add to the current knowledge of the signaling networks, which are involved in root hair development and growth regulated by nutrients.
\end{abstract}

Keywords: calcium; iron; magnesium; nitrogen; phosphorus; potassium; root hair; ROS

\section{Introduction of root hairs}

The absorption of nutrients from soil is considered to be the main function of plant root hairs, which are long tubular-shaped outgrowths from root epidermal cells (Salazar-Henao et al., 2016; Huang et al., 2019; Liu et al., 2020). In citrus (trifoliate orange), root hairs rapidly grow, at a rate of $0.5 \mu \mathrm{m} / \mathrm{min}$. They are approximately $14 \mu \mathrm{m}$ in diameter and can grow to be $110 \mu \mathrm{m}$ or more in length (Figure 1).

Root hairs have attracted a great deal of attention from plant scientists because their growth is a good subject for basic studies of plant cell biologists and physiologists (Grierson et al., 2015). As shown in Figure 2, citrus (trifoliate orange) roots grew along the surface of agarose-solidified nutrient medium in verticallyoriented petri plates, and root hairs are easily visualized using a stereomicroscope. Furthermore, the development and growth of root hairs occurs in a predictable and progressive manner in cells organized in files emanating from the root tip (Figure 3). This provides the opportunity for analysis of the cellular changes that occur during the process of root hair initiation and elongation.

Received: 09 Feb 2021. Received in revised form: 30 Mar 2021. Accepted: 27 Apr 2021. Published online: 14 Jun 2021.

From Volume 49, Issue 1, 2021, Notulae Botanicae Horti Agrobotanici Cluj-Napoca journal uses article numbers in place of the traditional method of continuous pagination through the volume. The journal will continue to appear quarterly, as before, with four annual numbers. 


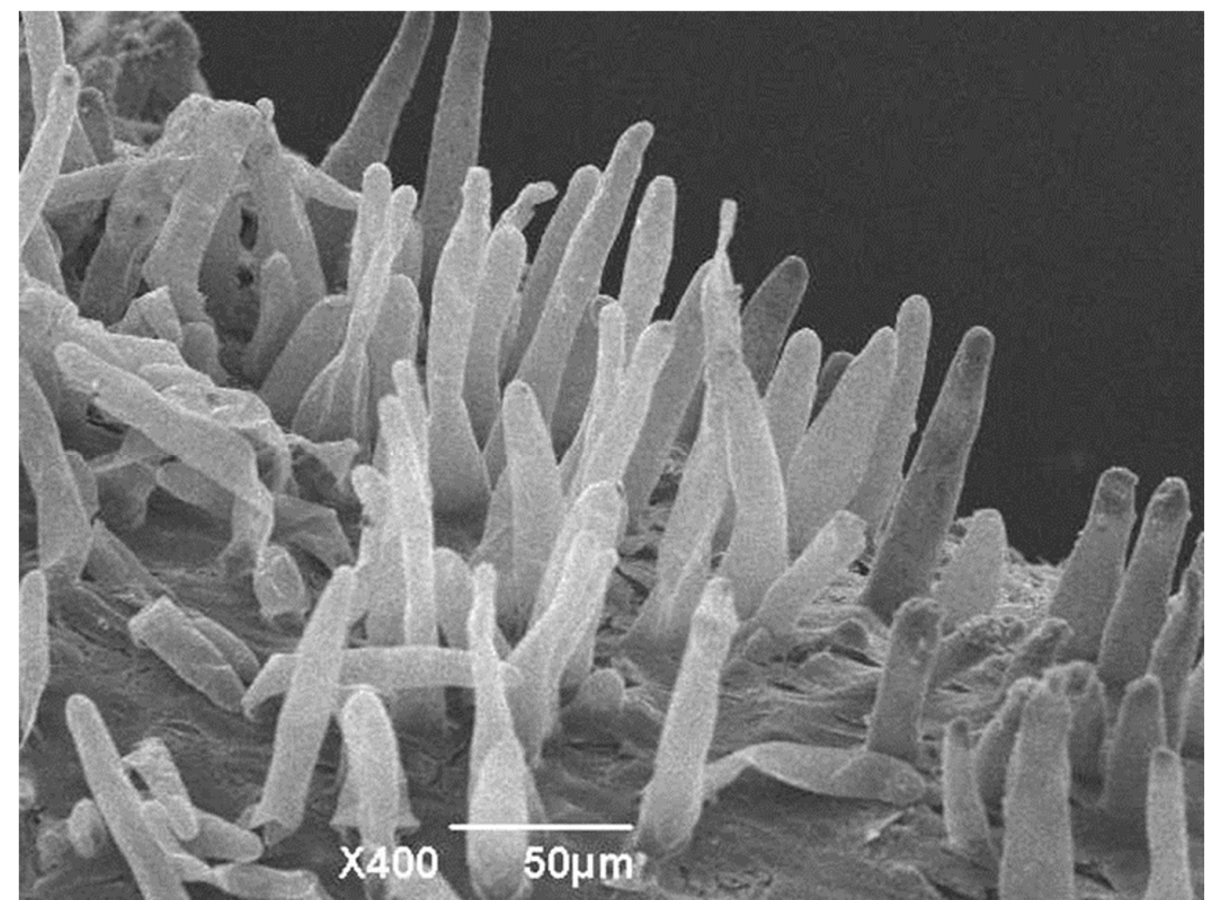

Figure 1. Scanning electron micrograph of root hairs of citrus (trifoliate orange)

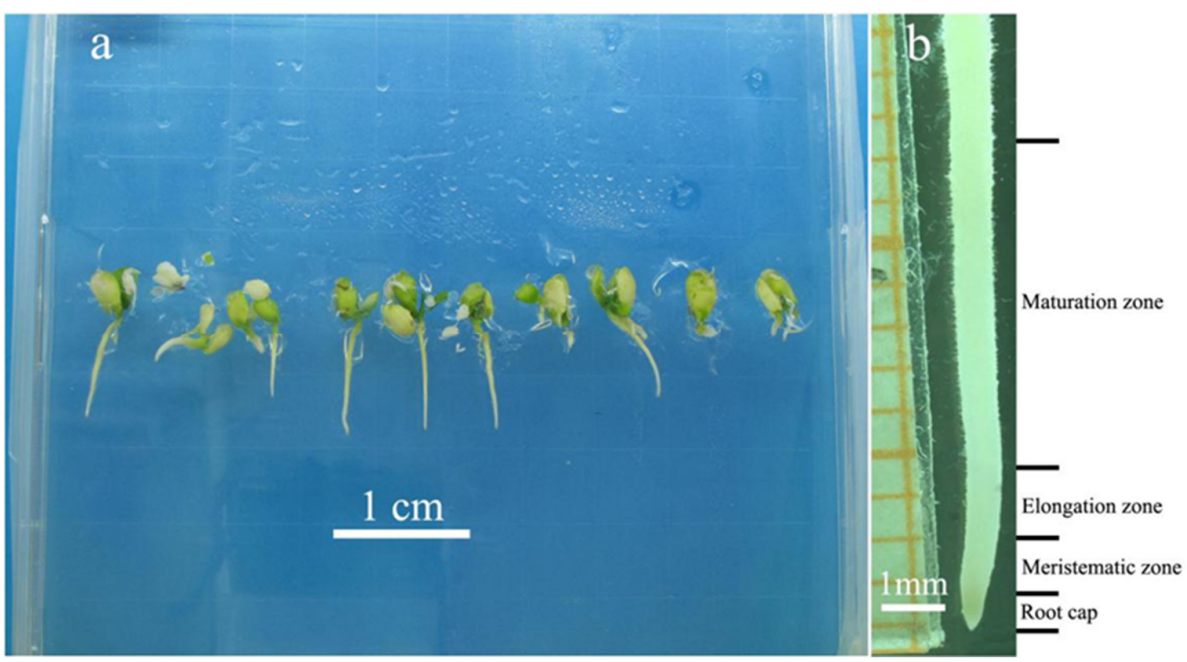

Figure 2. Development of citrus (trifoliate orange) seedlings growing on agarose-solidified nutrient medium in vertically-oriented Petri plates (a). The roots grew along the surface of the medium, and root hairs are easily visualized by using a stereomicroscope (b)

\section{Root hair specification}

The specification patterns of root hairs have been divided into 3 types (Kim et al., 2006; Kim and Dolan, 2011). In type 1, root hair cells can be differentiating from other epidermal cells, such as in Soleirolia soleirolii and Poncirus trifoliata (Clowes 2000; Zhang et al., 2013). In type 2, the root epidermis consists of long and short cells, but only the short cells can initiate root hairs, such as in Oryza sativa (Kim and Dolan, 2011). Type 3 root hairs are located over epidermal cells (trichoblasts) which overly the junction of two cortical cells, whereas epidermal cells (atrichoblasts) which are located outside periclinal cortical cell walls cannot initiate root hairs, such as in Arabidopsis (Dolan and Costa, 2001; Grierson, 2014). Specifically, trichoblasts display a 
greater cytoplasmic density, unique cell surface ornamentation, greater rate of cell division, distinct cell wall epitopes, and a lower rate of vacuolation (Grierson, 2014).

More precisely type 3 patterning information is governed by a network of transcriptional regulators. The GL2 (GLABRA2), which is the basic helix-loop-helix (bHLH) transcriptional activator, encodes a homeodomain transcription factor protein (Chen and Wang, 2019; Han et al., 2020). The GL2 gene is preferentially expressed in atrichoblasts within the meristematic and elongation regions of the root (Grierson, 2014; Chen and Wang, 2019). Careful examination using the GL2 reveals position-dependent gene expression within, or just one cell beyond, which implies that patterning information may be provided within these initial cells (Berger et al., 1998).

The WER (WEREWOLF) gene encodes a MYB transcription factor of the R2-R3 class (Lee and Schiefelbein, 1999; Wang et al., 2019). It is preferentially expressed in developing epidermal cells in atrichoblasts, which are the cells whose fate is mis-specified in the wer mutant (Grierson, 2014). In addition to the MYB DNA-binding domains, the WER protein possesses a phosphatidic acid (PA)-interacting region involved in nuclear localization (Yao et al., 2013). The Arabidopsis wer mutant forms root hairs on essentially every root epidermal cell, which implies that the normal role of WER is to promote atrichoblast cell differentiation and repress trichoblast cell differentiation (Yao et al., 2013; Grierson, 2014).

The TTG (TRANSPARENT TESTA GLABRA) gene encodes a small protein with WD40 repeats (Long and Schiefelbein, 2020). Long and Schiefelbein (2020) demonstrated the crucial role of TTG for the appropriate balance of target gene activation to achieve the proper pattern of root hair cell types during root development. TTG is able to physically interact with the basic helix-loop-helix (bHLH) transcriptional activator $G L 2$ and MYB transcription factor WER which implies that a tripartite transcription factor complex is responsible for directing the non-hair cell fate (Song et al., 2011; Grierson, 2014).

Another the basic helix-loop-helix (bHLH) transcriptional gene, CPC (CAPRICE), causes root epidermis cells to differentiate to root hair cells (Kirik et al., 2004; Savage et al., 2013). Rather than causing ectopic root hair cells, the $c p c$ mutant produces a reduced number of root hair cells (Wada et al., 1997; Savage et al., 2013). This implies that $C P C$ is a positive regulator of the root hair cell fate. The g/2 mutation is epistatic to $c p c$, which suggests that $C P C$ acts in the $W E R / T T G / G L 2$ pathway as a negative regulator of GL2 (Grierson, 2014). CPC can inhibit the function of the WER-GL3/EGL3-TTG complex by interfering with WER binding to GL3/EGL3 in a competitive manner (Song et al., 2011; Kang et al., 2013).

The SCRAMBLED (SCM) gene differs from the preceding genes because its mutant phenotype does not eliminate one of the epidermal cell types but merely alters the distribution of root hair cells and non-hair cells (Kwak et al., 2005; Kwak and Schiefelbein, 2014). SCM, an atypical leucine-rich repeat receptor-like kinase (LRR RLK) mediates the positional information to the epidermal cells and preferentially accumulates in cells adopting the root hair cell fate (Kwak et al., 2005; Kwak and Schiefelbein, 2014). Interestingly, the $S C M$ gene is itself under the transcriptional feedback regulation of the WER-GL3/EGL3-TTG complex, because atrichoblast cells exhibit a complex-dependent reduction in $S C M$ accumulation, relative to trichoblast cells (Kwak and Schiefelbein, 2008). This negative regulatory loop may serve to amplify SCM signaling in trichoblast cells.

Figure 4 shows a model for the specification of trichoblast (root hair cell) and atrichoblast (non-hair cell) types in the Arabidopsis root epidermis (modified from Bruex et al., 2012; Grierson, 2014). The proposed accumulation and interaction of cell fate regulators is shown within root epidermal cells destined to be trichoblast cells (in root hair cells) or atrichoblast cells (in the non-root hair cells). In this model, the pattern of hair and non-hair cell types relies on the relative activity of two competing sets of transcription factors, the R2R3 WER and MYB23 proteins vs. the one-repeat Mybs CPC, TRY, and ETC1 (Grierson, 2014). 


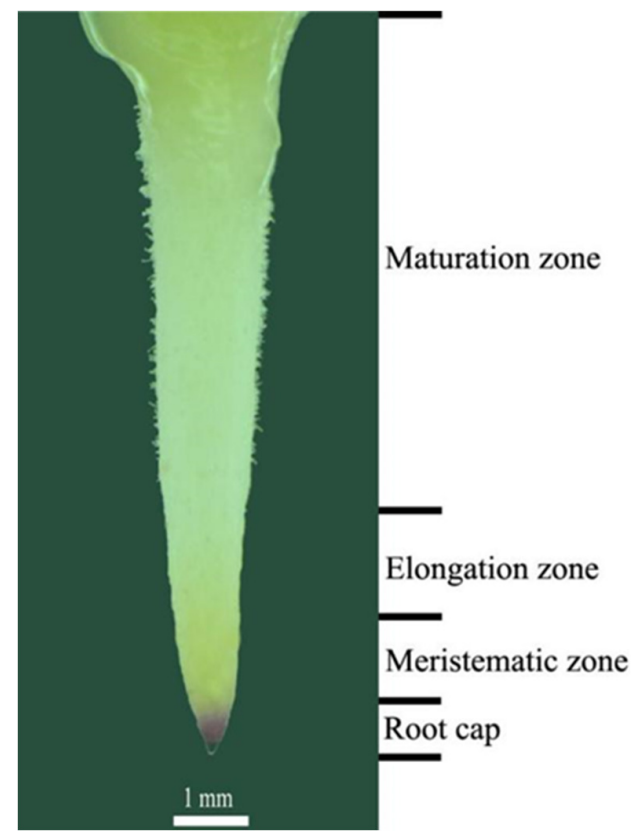

Figure 3. Photograph of the root tip showing the progressive development of root hairs of citrus (trifoliate orange)

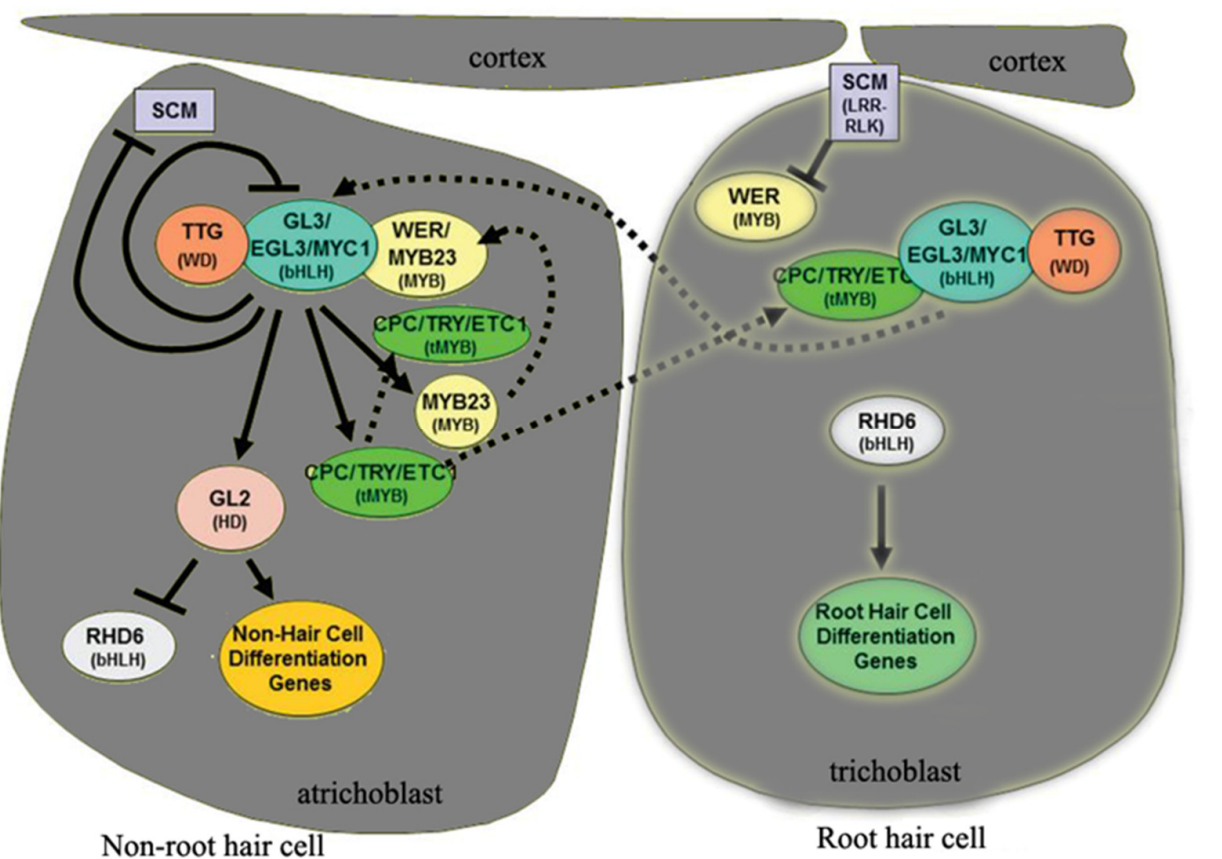

Figure 4. Model for the specification of trichoblasts and atrichoblasts in the Arabidopsis root epidermis (modified from Bruex et al., 2012; Claire, 2014)

Note: The default fate for an epidermal cell is a root hair cell. Arrows indicate positive control, blunt lines indicate negative regulation, and broken lines indicate intercellular or intracellular protein movement.

These are able to form an active or inactive complex, respectively, with the TTG and GL3/EGL3 proteins. In immature epidermal cells in the atrichoblast cell position, it is proposed that a relatively high level 
of WER is present and this predominately leads to the formation of the active complex, expression of $G L 2$ (and probably other genes), and non-hair cell differentiation (Grierson, 2014). On the other hand, immature epidermal cells located in the trichoblast cell position are proposed to accumulate a relatively high level of $C P C$, which leads to inactive complexes, repression of $G L 2$, and root hair cell differentiation (Grierson, 2014). SCM is proposed to mediate the effects of a position cue and initiate differential accumulation of the WER and CPC regulators (Grierson, 2014). The downstream feedback loops, including the negative effect of $C P C$ and positive regulation by MYB23, are thought to stabilize and amplify the initial asymmetry in gene expression patterns (Grierson, 2014).

After specification, root hairs enter the phase of tip growth. Plants' root hair tip growth can be influenced by soil permeability and edaphon, plant growth regulators, and mineral nutrients. Many researchers focused on the effects of phytohormones (such as auxins, ethylene, jasmonic acid, methyl jasmonate, strigolactone, and brassinosteroids) on root hair growth. However, research on nutrients affecting root hair development and growth is of great significance because the soil is often deficient in nutrients.

\section{Effect of root hairs on nutrients acquisition}

Root hairs can greatly increase the root surface area and hence vastly facilitate the absorption of nutrients from the soil. Water channels, as well as calcium, phosphate, and potassium, are located in the root hair surface area, and it has been suggested that root hairs take part in the absorption of most nutrients in plants (Libault et al., 2010). Even more, Wang et al. (2016) considered that long and dense root hairs are important traits in ensuring efficient absorption of nutrients in the early establishment of plants in nutrient-limited soil and low nutrients input environment cropping systems. As an adaptive response to nutrient deficiency, an increase in root hair length and density enhances root-soil contact and the absorptive area for nutrient absorption (Kohli et al., 2020). For example, the Arabidopsis mutant has more and longer root hairs which are more efficient in acquiring phosphate from infertile soil environments (Huang et al., 2018; Narang et al., 2000). Root hairs play a crucial role in nutrients acquisition by contributing 20-80\% to the total nutrient uptake (Jungk, 2001; Kohli et al., 2020).

\section{Root hair growth in response to nutrients}

\section{Calcium}

The calcium ion $\left(\mathrm{Ca}^{2+}\right)$ is involved in most biological processes in the plant kingdom (Tortosa et al., 2019). As a second messenger, $\mathrm{Ca}^{2+}$ regulates a multitude of adaptational and physiological processes in plants, including cell expansion, cell division, responses to abiotic stress, cytoplasmic streaming, and pathogen defense (Westphal et al., 2019). Cytoplasmic $\mathrm{Ca}^{2+}$ regulates cytoskeletal rearrangements and vesicular trafficking in tipgrowing systems such as root hair growth and development (Hepler et al., 2001). Wymer et al. (1997) reported that the $\mathrm{Ca}^{2+}$ gradient exists in growing root hairs, which is most pronounced in rapidly elongating root hairs. Studies have shown that a growing root hair has a localized gradient of $\mathrm{Ca}^{2+}$ concentration toward the growing apex, and the intensity of this gradient correlates with the growth rate of the root hairs (Takeda et al., 2008; Li et al., 2012). Confocal ratio imaging demonstrated that a tip-focused $\mathrm{Ca}^{2+}$ gradient is centered at the site of active growth of root hairs (Bibikova et al., 1997). Imposing an artificial tip-focused $\mathrm{Ca}^{2+}$ gradient reorients root hair growth toward the new gradient (Bibikova et al., 1997; Gilroy and Jones, 2000). Further evidence for the role of $\mathrm{Ca}^{2+}$, using $\mathrm{Ca}^{2+}$ ionophores and channel blockers, suggests that disruption the $\mathrm{Ca}^{2+}$ concentration gradient results in inhibiting root hair tip growth (Wymer et al., 1997).

Foreman et al. (2003) and Takeda et al. (2008) showed that ROS produced by NADPH oxidase activates $\mathrm{Ca}^{2+}$ channels in the apical plasma membrane, leading to the tip-focused $\mathrm{Ca}^{2+}$ concentration gradient required for root hairs tip growth. Additional evidence from the Arabidopsis $r$ hd 2 mutant indicates that 
application of exogenous ROS to in vivo root apices stimulates cell growth and $\mathrm{Ca}^{2+}$ influxes in root hairs, which induce root hair elongation (Foreman et al., 2003). The positive effect of exogenous ROS on root hair growth and development can be blocked by pharmacological inhibitors of calcium channels (Foreman et al., 2003). Artificially increasing cytosolic $\mathrm{Ca}^{2+}$ by treatment with calcium ionophore $\mathrm{A} 23187$ (mixed calciummagnesium salt) induces production of elevated level of ROS around the root hair tip and inhibits tip growth because these large amounts of ROS disrupt the $\mathrm{Ca}^{2+}$ concentration gradient (Foreman et al., 2003).

As a consequence, the $\mathrm{Ca}^{2+}$ concentration gradient is a requirement in sustaining root hair growth and ROS can activate the calcium channel-mediated influx of $\mathrm{Ca}^{2+}$, which creates a $\mathrm{Ca}^{2+}$ concentration gradient and subsequently regulates root hair growth.

\section{Iron}

Iron $(\mathrm{Fe})$ is an essential nutrient for plants because it catalyzes crucial cellular functions such as antioxidative cell protection, photosynthesis, chloroplast development, and chlorophyll synthesis. (Curie and Mari, 2017; Tsai and Schmidt, 2017). Although Fe is one of the most abundant elements in soils, it is mainly insoluble and non-available to plants (Tsai and Schmidt, 2017). So, plants have evolved efficient strategies to increase iron solubility and absorption efficiency, such as increasing root hairs (Cao et al. 2013). The number of root hairs was increased in response to Fe deficiency in Arabidopsis and citrus (Muller and Schmidt, 2004; Cao et al., 2013). Fe regulates root hair growth and development through the plant ferredoxin-like protein (PFLP), which affects ROS content by NADPH oxidase (NOX) (Sundaravelpandian et al., 2013; Nestler et al., 2014; Lin et al., 2015). Further evidence suggests that Fe has an interactive effect with ethylene on root hair initiation and elongation. Fe deficiency can lead to the formation of extra root hairs located in positions normally occupied by non-hair cells, which is dependent on ethylene signaling and requires functional EIN2 and ETR1 genes (Schmidt and Schikora, 2001).

\section{Magnesium}

Magnesium $(\mathrm{Mg})$ is one of the essential nutrients for plants, playing a key role in plant metabolic processes and reactions, such as in photosynthesis as the central atom in chlorophyll, protein synthesis, phloem loading, photosynthetic $\mathrm{CO}_{2}$ fixation, and generation of ROS (Wang et al., 2020). $\mathrm{Mg}$ is also involved in a series of enzyme activities and protein synthesis, functioning as a bridge element between enzymes and substrates (Shaul, 2002; Gransee and Führs, 2013).

Recently, the effect of interactions among $\mathrm{Mg}, \mathrm{ROS}$, and $\mathrm{Ca}^{2+}$ on root hairs was reported. Low $\mathrm{Mg}$ availability results in longer and denser root hairs in Arabidopsis with higher concentrations of ROS and $\mathrm{Ca}^{2+}$ in the root tip and the root hair tip (Niu et al., 2014). However, when treated with diphenylene iodonium (an NADPH-oxidase inhibitor) or 1,2-bis (o-aminophenoxy) ethane-N,N,N',N',-tetraacetic acid (a $\mathrm{Ca}^{2+}$ chelator), the $\mathrm{Ca}^{2+}$ concentration gradient was eliminated for the enhanced growth of root hairs in low-Mg treatment (Yoshioka et al., 2001; Kadota et al., 2004). However, root hair development was blocked in high$\mathrm{Mg}$ treatment and its inhibiting effect was restored when supplied with $\mathrm{CaCl}_{2}$ or phenazine methosulfate (a ROS generator) in Arabidopsis (Zhang et al., 2009; Niu et al., 2014). Niu et al. (2014) found that NADPH oxidase in roots is positively regulated by low $\mathrm{Mg}$ and is inhibited by high $\mathrm{Mg}$ levels, which is further evidence that $\mathrm{Mg}$ can control ROS in regulating root hair development. Therefore, the growth of root hairs is closely related to $\mathrm{Mg}$ availability by $\mathrm{ROS}$ and $\mathrm{Ca}^{2+}$ signaling.

\section{Nitrogen}

Ammonium $\left(\mathrm{NH}_{4}^{+}\right)$and nitrate $\left(\mathrm{NO}_{3}{ }^{-}\right)$are the major forms of inorganic nitrogen absorbed in plants, which can increase the nutrient uptake to the optimal uptake of essential elements (Tavakoli Hasanaklou, 2020). There is clear molecular and electrophysiological evidence that root hair growth is regulated by $\mathrm{NH}_{4}^{+}$ and $\mathrm{NO}_{3}$. Expression of two putative $\mathrm{NH}_{4}^{+}$and $\mathrm{NO}_{3}{ }^{-}$transporters genes (LeNRT1-2 and LeAMTI) is root hair specific in tomato, which is regulated by an external N supply (Becker et al., 2002). Direct evidence using 
scanning electron microscopy suggested that split root hairs are initiated in Arabidopsis thaliana after the addition of $\mathrm{NH}_{4} \mathrm{NO}_{3}$ to its roots (Yang et al., 2011). Yang et al. (2011) considers that the effects of $\mathrm{NH}_{4}^{+}$and $\mathrm{NO}_{3}{ }^{-}$on split root hairs may be through the methyl jasmonate or ethylene signaling pathways, and that methyl jasmonate enhances the effect on split root hairs while ethylene decreases it. Furthermore, $\mathrm{NH}_{4}{ }^{+}$and $\mathrm{NO}_{3}{ }^{-}$may regulate calcium ions $\left(\mathrm{Ca}^{2+}\right)$ in root hair cells through Rho-related GTPase from plants and reactive oxygen species (Bloch et al., 2011; Bai et al., 2014). Thus, N may have interactions with hormones, ROS, and calcium in regulating root hair growth.

\section{Phosphorus}

Phosphorus $(\mathrm{P})$ is extremely immobile in the soil and plays a variety of essential roles in plants (Kohli et al., 2020). It is an important mineral nutrient in plants, not only as a constituent of key cellular molecules such as ATP, phospholipids, and nucleic acids, but also has a pivotal role in cellular signaling, energy conservation and metabolic regulation (Shin et al., 2005; Macdonald et al., 2011; Kohli et al., 2020).

Many studies focused on understanding the mechanistic basis of $\mathrm{P}$ efficiency in order to develop crops that require less $\mathrm{P}$ input. Root hairs play a crucial role in $\mathrm{P}$ acquisition by contributing $50-80 \%$ to the total $\mathrm{P}$ uptake (Gahoonia and Nielsen, 1998; Jungk, 2001). P deficiency in the soil often induces dense root hairs in plants such as Arabidopsis and citrus (Zhu et al., 2005; Cao et al., 2013). In P deficient soil, the length and density of Arabidopsis root hairs significantly increases, expanding the root's surface area from $0.21 \mathrm{~mm}^{2} \mathrm{~mm}^{-1}$ root under $\mathrm{P}$ sufficient conditions to $1.44 \mathrm{~mm}^{2} \mathrm{~mm}^{-1}$ roots under $\mathrm{P}$ starvation conditions, with root hairs constituting $91 \%$ of the total root's surface area (Bates and Lynch, 1996). In addition, the response to P deprivation in root hairs is accompanied by an increase in ROS, which is necessary for root hair initiation and elongation through the $\mathrm{Ca}^{2+}$ gradient (Carol and Dolan, 2006). In addition to ROS, auxins also participate in the interaction between root hair growth and P. Activation of the AUXIN RESPONSE FACTOR19 (ARF19) in low P conditions activates an important key basic helix-loop-helix (bHLH) transcription factor, ROOT HAIR DEFECTIVE6-LIKE 4 (RSL4), facilitating root hair growth and development (Bhosale et al., 2018; Giri et al., 2018). Thus, there is an interactive between ROS, auxins, and P on root hair growth and development.

\section{Potassium}

Potassium ion $\left(\mathrm{K}^{+}\right)$is the most abundant cation in cells of plants, and plays a crucial role in plant development, such as enzyme homeostasis, leaf movements, assimilating transport, photosynthesis, and enzyme activation (Miao et al., 2010). K deficiency not only reduces mechanical stability, nutritional quality, and crop resistance to pathogens but also decreases root hair growth, such as in citrus root hairs (Cao et al., 2013). Gassmann and Schroeder (1994) considered that inward-rectifying $\mathrm{K}^{+}$channels in root hairs can function as both a physiologically important mechanism for low-affinity $\mathrm{K}^{+}$uptake and as regulators of membrane potential. TRH1 (AtKT/AtKUP/HAK K ${ }^{+}$transporter family) was demonstrated in Arabidopsis that its mutant $t r h 1$ partially impairs $\mathrm{K}^{+}$transport, which also blocks root hair development (Rigas et al., 2001). However, trh1 cannot restore its defected root hair phenotype when it is grown at high external $\mathrm{K}$ concentrations (Rigas et al., 2001). This demonstrates that TRH1 mediates $\mathrm{K}^{+}$transport in Arabidopsis roots and is responsible for specifics $\mathrm{K}^{+}$translocation, which is essential for root hair growth (Rigas et al., 2001).

Interestingly, studies found that $\mathrm{K}$ interacts with ethylene and auxins on root hair growth and development. When under $\mathrm{K}$ stress, both ethylene production and its biosynthesis gene expressions were increased (Jung et al., 2009). Ethylene signaling is a component of the plant's response to low $\mathrm{K}$ that stimulates reactive oxygen species (ROS) production which is important for changes in root hair morphology (Jung et al., 2009). Rigas et al. (2013) consider that auxins modulate root hair specification at the differentiation zone. TRH1 (the potassium transporter) is cell-specifics subcellular localized in the stele and epidermis, which engages in auxin transport and redistribution (Rigas et al., 2013). TRHI has a role in the sensing of external $\mathrm{K}^{+}$ and the regulation of K dependent root hair growth (Rigas et al., 2013). In the Arabidopsis mutant $t r h 1$, auxin 
imbalance causes poor root hairs (Vicente-Agullo et al., 2004; Rigas et al., 2013). Hence, K may regulate root hair growth and development though ethylene and auxin signaling.

\section{Conclusions}

To understand the development and function of a type of cell, the studies of root hairs have provided a useful and visual model to clarify new insights into general principles for plant cell biologists and physiologists, such as the inherent flexibility and plasticity in the growth and development of plant cells, in that the flexibility and plasticity are important for plants to adequately respond to their changing environment.

Improving plants to give root hairs high efficiency for nutrient absorption could reduce the adverse impact from stressful environments as well as enhancing agricultural sustainable development. More study is needed on the effects of nutrients on root hair development and growth, while root hair morphogenesis is driven by an amalgam of interacting processes controlled by complex signaling events. Some of the major factors involved in the signaling process during root hair growth and development have been identified, such as $\mathrm{N}$, $\mathrm{Ca}^{2+}, \mathrm{Mg}^{2+}$, and $\mathrm{P}$. It is not clear how these signaling component interactions regulate root hairs at the molecular and cellular level or how these signals interact with phytohormones to regulate its development and growth, such as auxins, ethylene, and JAs. Furthermore, the role and regulatory mechanism of the $\mathrm{Ca}^{2+}$ gradient in root hair initiation and tip growth still needs further study.

More works are needed to clone the genes of additional root hair mutants and elucidate their roles, as well as add to our current knowledge of the signaling networks involving nutrients, ROS, and phytohormones regulation on root hair specification, initiation, and tip growth by reverse genetics and mutant complementation studies.

\section{Authors' Contributions}

Conceptualization: MFS and DJZ; Data curation: XH, ML, and CHH; Formal analysis: TZG; Funding acquisition: MFS and DJZ; Investigation: XH and TZG; Project administration: DJZ; Supervision: MFS; Writing - original draft: XH and TZG; Writing -review and editing: MFS and DJZ. All authors read and approved the final manuscript.

\section{Acknowledgements}

This work was supported by the Young and Middle-aged Talent Project of Hubei Provincial Education Department (grant number Q20181304), the National Natural Science Foundation of China (No. 32001984) and The Open Fund of Henan Key Laboratory of Tea Comprehensive utilization in South Henan (Xinyang Agriculture and Forestry University).

\section{Conflict of Interests}

The authors declare that there are no conflicts of interest related to this article. 


\section{References}

Bates TR, Lynch JP (1996). Stimulation of root hair elongation in Arabidopsis thaliana by low phosphorus availability. Plant Cell and Environment 19:529-538. https://doi.org/10.1111/j.1365-3040.1996.tb00386.x

Becker D, Stanke R, Fendrik I, Frommer WB, Vanderleyden J, ... Hedrich R (2002). Expression of the $\mathrm{NH}_{4}{ }^{+}$-transporter gene LEAMT1;2 is induced in tomato roots upon association with $\mathrm{N}_{2}$-fixing bacteria. Planta 215:424-429. https://doi.org/10.1007/s00425-002-0773-x

Berger F, Haseloff J, Schiefelbein J, Dolan L (1998). Positional information in root epidermis is defined during embryogenesis and acts in domains with strict boundaries. Current Biology 8:421-430. https://doi.org/10.1016/s0960-9822(98)70176-9

Bhosale R, Giri J, Pandey BK, Giehl RFH, Hartmann A, ... Swarup R (2018). A mechanistic framework for auxin dependent Arabidopsis root hair elongation to low external phosphate. Nature Communications 9:1409. https://doi.org/10.1038/s41467-018-03851-3

Bibikova TN, Zhigilei A, Gilroy S (1997). Root hair growth in Arabidopsis thaliana is directed by calcium and an endogenous polarity. Planta 203:495-505. https://doi.org/10.1007/s004250050219

Bloch D, Monshausen G, Gilroy S, Yalovsky S (2011). Co-regulation of root hair tip growth by ROP GTPases and nitrogen source modulated $\mathrm{pH}$ fluctuations. Plant Signaling and Behavior 6:426-429. https://doi.org/10.4161/psb.6.3.14523

Bruex A, Kainkaryam RM, Wieckowski Y, Kang YH, Bernhardt C, ... Schiefelbein J (2012). A gene regulatory network for root epidermis cell differentiation in Arabidopsis. PLoS Genetics 8:e1002446. https://doi.org/10.1371/journal.pgen.1002446

Cao X, Chen CL, Zhang DJ, Shu B, Xiao J, Xia RX (2013). Influence of nutrient deficiency on root architecture and root hair morphology of Trifoliata orange (Poncirus trifoliata L. Raf.) seedlings under sand culture. Scientia Horticulturae 162:100-105. https://doi.org/10.1016/j.scienta.2013.07.034

Carol RJ, Dolan L (2006). The role of reactive oxygen species in cell growth: lessons from root hairs. Journal Experimental Botany 57:1829-1834. https://doi.org/10.1093/jxb/erj201

Chen SY, Wang SC (2019). GLABRA2, A common regulator for epidermal cell fate determination and anthocyanin biosynthesis in Arabidopsis. International Journal of Molecular Sciences 20:4997. https://doi.org/10.3390/ijms20204997

Clowes FAL (2000). Pattern in root meristem development in angiosperms. New Phytologist 146:83-94. https://doi.org/10.1046/j.1469-8137.2000.00614.X

Curie C, Mari S (2017). New routes for plant iron mining. New Phytologist $214: 521$. https://doi.org/10.1111/nph.14364

Dolan L, Costa S (2001). Evolution and genetics of root hair stripes in the root epidermis. Journal Experimental Botany 52:413-417. https://doi.org/10.1093/jexbot/52.supp__1.413

Foreman J, Demidchik V, Bothwell JH, Mylona P, Miedema H, ... Dolan L (2003). Reactive oxygen species produced by NADPH oxidase regulate plant cell growth. Nature 422:442-446. https://doi.org/10.1038/nature01485

Gahoonia TS, Nielsen NE (1998). Direct evidence on participation of root hair in phosphorus $\left({ }^{32} \mathrm{P}\right)$ uptake from soil. Plant and Soil 198:147-152. https://www.jstor.org/stable/24122651

Gassmann W, Schroeder JI (1994). Inward-rectifying $\mathrm{K}^{+}$channels in root hairs of wheat: A mechanism for aluminumsensitivelow-affinity $\mathrm{K}^{+}$uptake and membrane potential control. Plant Physiology 105:1399-1408. https://doi.org/10.1104/pp.105.4.1399

Gilroy S, Jones DL (2020). Through form to function: root hair development and nutrient uptake. Trends in Plant Science 5:56-60. https://doi.org/10.1016/s1360-1385(99)01551-4

Giri J, Bhosale R, Huang G, Pandey BK, Parker H, Bennett MJ (2018). Rice auxin influx carrier OsAUX1 facilitates root hair elongation in response to low external phosphate. Nature Communications 9:1408. https://doi.org/10.1038/s41467-018-03850-4

Grierson CS, Parker JS, Kemp AC (2015). Arabidopsis genes with roles in root hair development. Journal of Plant Nutrition and Soil Science 164:131-140. http://dx.doi.org/10.1002/1522-2624(200104)164:2<131::AIDJPLN131>3.3.CO;2-2

Grierson C, Nielsen E, Ketelaar T, Schiefelbein J (2014). Root hairs. The Arabidopsis book, American Society of Plant Biologists 12:e0172. http://dx.doi.org/10.1199/tab.0060 
Han GL, Wei XC, Dong XX, Wang CF, Sui N, ... Wang BS (2020). Arabidopsis ZINC FINGER PROTEIN1 acts downstream of $G L 2$ to repress root hair initiation and elongation by directly suppressing bHLH genes. The Plant Cell 32:206-225. https://doi.org/10.1105/tpc.19.00226

Hepler PK, Vidali L, Cheung AY (2001). Polarized cell growth in higher plants. Annual Review of Cell and Developmental Biology 17:159-187. https://doi.org/10.1146/annurev.cellbio.17.1.159

Huang C, Jiao X, Yang L, Yang L, Zhang M, ... Song C (2019). ROP-GEF signal transduction is involved in AtCAP1regulated root hair growth. Plant Growth Regulation 87:1-8. https://doi.org/10.1007/s10725-018-0448-7

Huang G, Liang W, Sturrock CJ, Pandey BK, Giri J, ... Zhang D (2018). Rice actin binding protein RMD controls crown root angle in response to external phosphate. Nature Communications 9:2346. https://doi.org/10.1038/s41467018-04710-X

Jung JY, Shin R, Schachtman DP (2009). Ethylene mediates response and tolerance to potassium deprivation in Arabidopsis. The Plant Cell 21: 607. https://doi.org/10.1105/tpc.108.063099

Jungk A (2001). Root hairs and the acquisition of plant nutrients from soil. Journal of Plant Nutrition and Soil Science 164:121-129. https://doi.org/10.1002/1522-2624(200104)164:23.0.CO;2-6

Kadota Y, Goh T, Tomatsu H, Tamauchi R, Higashi K ... Kuchitsu K (2004). Cryptogein-induced initial events in tobacco BY-2 cells:pharmacological characterization of molecular relationship among cytosolic $\mathrm{Ca}^{2+}$ transients, anion efflux and production of reactive oxygen species. Plant Cell and Physiology 45:160-170. https://doi.org/10.1093/pcp/pch020

Kang YH, Song SK, Schiefelbein J, Lee MM (2013). Nuclear trapping controls the position-dependent localization of CAPRICE in the root epidermis of Arabidopsis. Plant Physiology 163:193-204. https://doi.org/10.1104/pp.113.221028

Kim CM, Dolan L (2011). Root hair development involves asymmetric cell division in Brachypodium distachyon and symmetric division in Oryza sativa. New Phytologist 192:601-610. https://doi.org/10.1111/j.14698137.2011.03839.x

Kim DW, Lee SH, Choi SB, Won SK, Heo YK, ... Cho HT (2006). Functional conservation of a root hair cell-specific cis-element in angiosperms with different root hair distribution patterns. The Plant Cell 18:2958-2970. https://doi.org/10.1105/tpc.106.045229

Kirik V, Simon M, Huelskamp M, Schiefelbein J (2004). The enhancer of try and CPC1 gene acts redundantly with TRIPTYCHON and CAPRICE in trichome and root hair cell patterning in Arabidopsis. Developmental Biology 268:506-513. https://doi.org/10.1016/j.ydbio.2003.12.037

Kohli PS, Verma PK, Verma R, Parida SK, Giri J (2020). Genome-wide association study for phosphate deficiency responsive root hair elongation in chickpea. Functional \& Integrative Genomics 20:1-12. https://doi.org/10.1007/s10142-020-00749-6

Kwak SH, Schiefelbein J (2014). TRIPTYCHON, not CAPRICE, participates in feedback regulation of SCM expression in the Arabidopsis root epidermis. Plant Signaling \& Behavior 9:e973815. https://doi.org/10.4161/15592324.2014.973815

Kwak SH, Shen R, Schiefelbein J (2005). Positional signaling mediated by a receptor-like kinase in Arabidopsis. Science 307:1111-1113. https://doi.org/10.1126/science.1105373

Kwak SH, Schiefelbein J (2008). A feedback mechanism controlling SCRAMBLED receptor accumulation and cell-type pattern in Arabidopsis. Current Biology 18:1949-1954. https://doi.org/10.1016/j.cub.2008.10.064

Lee MM, Schiefelbein J (1999). WEREWOLF, a MYB-related protein in Arabidopsis, is a position-dependent regulator of epidermal cell patterning. Cell 99:473-483. https://doi.org/10.1016/S0092-8674(00)81536-6

Li S, Yu JL, Zhu M, Zhao F, Luan S (2012). Cadmium impairs ion homeostasis by altering $\mathrm{K}^{+}$, and $\mathrm{Ca}^{2+}$, channel activities in rice root hair cells. Plant, Cell and Environment 35:1998-2013. https://doi.org/10.1111/j.13653040.2012.02532.x

Libault M, Brechenmacher L, Cheng J, Xu D, Stacey G (2010). Root hair systems biology. Trends in Plant Science 15:641650. https://doi.org/10.1016/j.tplants.2010.08.010

Lin CY, Huang LY, Chi WC, Huang TL, Kakimoto T, ... Huang HJ (2015). Pathways involved in vanadate-induced root hair formation in Arabidopsis. Physiologia Plantarum 153:137-148. https://doi.org/10.1111/ppl.12229

Liu CY, Zhang F, Zhang DJ, Zou YN, Shu B, Wu QS (2020). Transcriptome analysis reveals improved root hair growth in trifoliate orange seedlings by arbuscular mycorrhizal fungi. Plant Growth Regulation 92:195-203. https://doi.org/10.1007/s10725-020-00630-3 
Long Y, Schiefelbein J (2020). Novel TTG1 mutants modify root-hair pattern formation in Arabidopsis. Frontiers in Plant Science 11:383. https://doi.org/10.3389/fpls.2020.00383

Macdonald GK, Bennett EM, Potter PA, Ramankutty N (2011). Agronomic phosphorus imbalances across the world's croplands. Proceedings of the National Academy of Sciences of the United States of America 108:3086-3091. https://doi.org/10.1073/pnas.1010808108

Miao BH, Han XG, Zhang WH (2010). The ameliorative effect of silicon on soybean seedlings grown in potassiumdeficient medium. Annals of Botany 105:967-973. https://doi.org/10.1093/aob/mcq063

Muller M, Schmidt W (2004). Environmentally induced plasticity of root hair development in Arabidopsis. Plant Physiology 134:409-419. https://doi.org/10.1104/pp.103.029066

Narang RA, Bruene A, Altmann T (2000). Analysis of phosphate acquisition efficiency in different Arabidopsis accessions. Plant Physiology 124:1786-1799. https://doi.org/10.1104/pp.124.4.1786

Nestler J, Liu S, Wen TJ, Paschold A, Marcon C, ... Hochholdinger F (2014). Roothairless5, which functions in maize (Zea mays L.) root hair initiation and elongation encodes a monocot-specific NADPH oxidase. The Plant Journal 79:729-740. https://doi.org/10.1111/tpj.12578

Niu Y, Jin G, Yong SZ (2014). Root development under control of magnesium availability. Plant Signaling \& Behavior 9:e29720. https://doi.org/10.4161/psb.29720

Rigas S, Debrosses G, Haralampidis K, Vicente-Agullo F, Feldmann KA, ... Hatzopoulos P (2001). TRH1 encodes a potassium transporter required for tip growth in Arabidopsis root hairs. The Plant Cell 13:139-151. https://doi.org/10.1105/tpc.13.1.139

Rigas S, Ditengou FA, Ljung K, Daras G, Tietz O, ... Hatzopoulos P (2013). Root gravitropism and root hair development constitute coupled developmental responses regulated by auxin homeostasis in the Arabidopsis root apex. New Phytologist 197:1130-1141. https://doi.org/10.1111/nph.12092

Salazar-Henao JE, Vélez-Bermúdez IC, Schmidt W (2016). The regulation and plasticity of root hair patterning and morphogenesis. Development 143:1848-1858. https://doi.org/10.1242/dev.132845

Savage N, Yang TJW, Chen CY, Lin KL, Monk NAM, Schmidt W (2013). Positional signaling and expression of ENHANCER OF TRY AND CPC1 are tuned to increase root hair density in response to phosphate deficiency in Arabidopsis thaliana. PLoS One 8:e75452. https://doi.org/10.1371/journal.pone.0075452

Schmidt W, Schikora A (2001). Different pathways are involved in phosphate and iron stress-induced alterations of root epidermal cell development. Plant Physiology 125:2078-2084. https://doi.org/10.1104/pp.125.4.2078

Shaul O (2002). Magnesium transport and function in plants: the tip of the iceberg. Biometals 15:309-323. https://doi.org/10.1023/A:1016091118585

Shin R, Berg RH, Schachtman DP (2005). Reactive oxygen species and root hairs in Arabidopsis root response to nitrogen, phosphorus and potassium deficiency. Plant Cell Physiology 46:1350-1357. https://doi.org/10.1093/pcp/pci145

Song SK, Ryu KH, Kang YH, Song JH, Cho YH, ... Lee MM (2011). Cell fate in the Arabidopsis root epidermis is determined by competition between Werewolf and Caprice. Plant Physiology 157:1196-208. https://doi.org/10.1104/pp.111.185785

Sundaravelpandian K, Chandrika NNP, Schmidt W (2013). PFT1, a transcriptional Mediator complex subunit, controls root hair differentiation through reactive oxygen species (ROS) distribution in Arabidopsis. New Phytologist 197:151-161. https://doi.org/10.1111/nph.12000

Takeda S, Gapper C, Kaya H, Bell E, Kuchitsu K, Dolan L (2008). Local positive feedback regulation determines cell shape in root hair cells. Science 319:1241-1244. https://doi.org/10.1126/science.1152505

Hasanaklou HT, Ghadim AEK, Moradi F, Ghodehkahriz SJ, Gholipouri A (2020). The effects of $\mathrm{NH}_{4}{ }^{+}$and $\mathrm{NO}_{3}{ }^{-}$and plant growth regulators on the accumulation of nutrients, carbohydrates and secondary metabolites of stevia rebaudiana bertoni. Sugar Tech 2020(2). https://doi.org/10.1007/s12355-020-00875-2

Tortosa M, Cartea ME, Velasco P, Soengas P, Rodriguez VM (2019). Calcium-signaling proteins mediate the plant transcriptomic response during a well-established Xanthomonas campestris pv. campestris infection. Horticulture Research 6:1-10. https://doi.org/10.1038/s41438-019-0186-7

Tsai HH, Schmidt W (2017). Mobilization of iron by plant-borne coumarins. Trends in Plant Science 22:538-548. https://doi.org/10.1016/j.tplants.2017.03.008

Vicente-Agullo F, Rigas S, Desbrosses G, Dolan L, Hatzopoulos P, Grabov A (2004). Potassium carrier TRH1 is required for auxin transport in Arabidopsis roots. The Plant Journal 40:523-535. https://doi.org/10.1111/j.1365$313 \times .2004 .02230 . x$ 
Wada T, Tachibana T, Shimura Y, Okada K (1997). Epidermal cell differentiation in Arabidopsis determined by a Myb homolog, CPC. Science 277:1113-1116. https://doi.org/10.1126/science.277.5329.1113

Wang W, Hui RK, Christa B, John S (2019). Root epidermal cell patterning is modulated by a critical residue in the WEREWOLF transcription factor. Plant Physiology 181:1239-1256. https://doi.org/10.1104/pp.19.00458

Wang Y, Kristian TK, Stoumann JL, Jakob M (2016). Vigorous root growth is a better indicator of early nutrient uptake than root hair traits in spring wheat grown under low fertility. Frontiers in Plant Science 7:865. https://doi.org/10.3389/fpls.2016.00865

Wang Y, Wu B, Berns AE, Xing Y, Amelung W (2020). Magnesium isotope fractionation reflects plant response to magnesium deficiency in magnesium uptake and allocation: a greenhouse study with wheat. Plant and Soil 455:93105. https://doi.org/10.1007/s11104-020-04604-2

Westphal L, Strehmel N, Eschen-Lippold L, Bauer N, Westermann B, ... Lee J (2019). pH effects on plant calcium fluxes: lessons from acidification-mediated calcium elevation induced by the $\gamma$-glutamyl-leucine dipeptide identified from Phytophthora infestans. Scientific Reports 9:4733. https://doi.org/10.1038/s41598-019-41276-0

Wymer CL, Bibikova TN, Gilroy S (1997). Cytoplasmic free calcium distribution during the development of root hairs of Arabidopsis thaliana. The Plant Journal 12:427-439. https://doi.org/10.1046/j.1365-313X.1997.12020427.X

Yang N, Zhu C, Gan L, Ng D, Xia K (2011). Ammonium-stimulated root hair branching is enhanced by methyl jasmonate and suppressed by ethylene in Arabidopsis thaliana. Journal of Plant Biology 54:92-100. https://doi.org/10.1007/s12374-011-9147-x

Yao H, Wang G, Guo L, Wang X (2013). Phosphatidic acid interacts with a MYB transcription factor and regulates its nuclear localization and function in Arabidopsis. The Plant Cell 25:5030-5042. https://doi.org/10.1105/tpc.113.120162

Yoshioka H, Sugie K, Park HJ, Maeda H, Doke N (2001). Induction of plant gp91 phox homolog by fungal cell wall, arachidonic acid, and salicylic acid in potato. Molecular Plant Microbe Interactions 14:725-736. https://doi.org/10.1094/MPMI.2001.14.6.725

Zhang DJ, Xia RX, Cao X, Shu B, Chen CL (2013). Root hair development of Poncirus trifoliata grown in different growth cultures and treated with 3-indolebutyric acid and ethephon. Scientia Horticulturae 160:389-397. https://doi.org/10.1016/j.scienta.2013.06.007

Zhang YY, Zhu HY, Zhang Q, Li M, Wang X (2009). Phospholipase D $\alpha 1$ and phosphatidic acid regulate NADPH oxidase activity and production of reactive oxygen species in ABA-mediated stomatal closure in Arabidopsis. The Plant Cell 21:2357-2377. https://doi.org/10.1105/tpc.108.062992

Zhu J, Kaeppler SM, Lynch JP (2005). Mapping of QTL controlling root hair length in maize (Zea mays L.) under phosphorus deficiency. Plant and Soil 270:299-310. https://doi.org/10.1007/s11104-004-1697-y
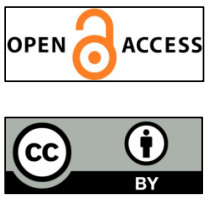

The journal offers free, immediate, and unrestricted access to peer-reviewed research and scholarly work. Users are allowed to read, download, copy, distribute, print, search, or link to the full texts of the articles, or use them for any other lawful purpose, without asking prior permission from the publisher or the author.

License - Articles published in Notulae Botanicae Horti Agrobotanici Cluj-Napoca are Open-Access, distributed under the terms and conditions of the Creative Commons Attribution (CC BY 4.0) License.

(c) Articles by the authors; UASVM, Cluj-Napoca, Romania. The journal allows the author(s) to hold the copyright/to retain publishing rights without restriction. 